\title{
Kalkulator Untuk Menghitung Korelasi Kesetaraan
}

\author{
Sigit Haryadi \\ Institut Teknologi Bandung
}

Paper DOII0.17605/OSF.IO/7R9JY

Haryadi, S. (2018, February 22). Kalkulator Untuk Menghitung Korelasi Kesetaraan. Retrieved from osf.io/preprints/inarxiv/7r9jy

\section{Ringkasan}

Metode korelasi kesetaraan adalah ukuran statistik yang menunjukkan sejauh mana suatu variabel acak yang diukur memiliki kemiripan dengan variabel rujukan, dimana penentuan tingkat korelasi dilakukan dengan menghitung Indeks Haryadi dari hubungan antara variabel acak yang diukur dengan variabel rujukan. Dalam hal ini, Indeks sama dengan satu adalah mewakili kesamaan yang sempurna antara elemen - elemen dari variabel yang diukur dengan pasangan elemen-elemen dari variabel rujukan, misalkan $R$ adalah variabel rujukan $=\{1,2,3,4,5,6,7,8,9,10,11\}$ dan $Y$ adalah variabel acak yang diukur $=\{2,4,6,8,10,12,14,16,18,20,22\}$, maka Y memiliki indeks korelasi kesetaraan sama dengan satu satu melalui fungsi hubungan $Y=2 R$, karena semua elemen dari $Y$ adalah sama dengan dua kali dari elemen pasangan dari $R$.

\section{Kalkulator Internet}

Untuk mempermudah perhitungan, telah dibuatkan suatu "kalkulator internet", yaitu suatu website yang menyediakan kolom isian, dimana kita dapat mengisikan nilai elemen -elemen dari variable yang diukur dan variable rujukan, lalu akan didapatkan indeks dan tingkat korelasi kesetaraan.

Prosedur: (1) Isilah ukuran dari variable acak yang diukur (Y), yang harus sama dengan ukuran dari variable rujukan (R), pastikan TIDAK ADA nilai dari suatu elemen yang sama dengan NOL; (2) isikan nilai dari setiap elemen Y dan R, lalu tekan CALCULATE

Alamat website tersebut adalah http://sigitharyadi.net/id/multidicipline/korelasi-kesetaraan/

\section{Penjelasan cara perhitungan}

I. Menghitung Variable Korelasi = Variabel Yang diukur dibagi dengan variable Rujukan, yang setiap elemennya adalah merupakan hasil bagi dari elemen dari variable acak yang diukur dengan elemen pasangan di variable rujukan. 
II. Menghitung share dari elemen - elemen Variable Korelasi, yaitu dengan menggunakan rumus: $\mathrm{Si}=$ (nilai dari suatu elemen variable korelasi dibagi dengan total dari seluruh elemen variable korelasi).

III. Lalu dihitung indeks korelasi kesetaraan menggunakan rumus " Indeks Haryadi" berikut ini:

$$
H I=\frac{1}{\left[N^{*}\left\{\sum_{i=1}^{N} S_{i}^{2}+\sum_{i=1}^{N} \sum_{j=1}^{N}\left(S_{i}-S_{j}\right)^{2}\right\}\right]} ; i>j
$$

IV. Lalu ditentukan tingkat kompetisi sebagai berikut:

a) Indeks Haryadi sama dengan 1,00 adalah bersesuaian dengan Tingkat Korelasi Kesetaraan yang sempurna.

b) Indeks Haryadi antara 0,95 sampai dengan 0,99 adalah bersesuaian dengan Tingkat Korelasi Kesetaraan yang sangat kuat.

c) Indeks Haryadi antara 0,90 sampai dengan 0,94 adalah bersesuaian dengan Tingkat Korelasi Kesetaraan yang kuat.

d) Indeks Haryadi antara 0,85 sampai dengan 0,89 bersesuaian dengan Tingkat Korelasi Kesetaraan yang hampir kuat.

e) Indeks Haryadi antara 0,75 sampai dengan 0,84 bersesuaian dengan Tingkat Korelasi Kesetaraan yang menengah.

f) Indeks Haryadi antara 0,60 sampai dengan 0,74 bersesuaian dengan Tingkat Korelasi Kesetaraan yang hampir lemah.

g) Indeks Haryadi antara 0,50 sampai dengan 0,59 bersesuaian dengan Tingkat Korelasi Kesetaraan yang lemah.

h) Indeks Haryadi kurang dari 0,50 adalah bersesuaian dengan Tingkat Korelasi Kesetaraan yang sangat lemah.

\section{Catatan}

Uraian lebih detil terdapat di daftar pustaka sebagai berikut:

\section{References}

[1] Sigit Haryadi. (2017). The Equality Correlation Method. Researchgate. DOI10.13140/RG.2.2.10443.80169.

[2] Haryadi, S. (2018, February 17). Calculation the Competition Levels between Students in Class and the Relation to the Teacher or Lecture Fairness in Teaching. Researchgate. DOI10.13140/RG.2.2.30359.06569

[3] Haryadi, S. (2018, February 17). Perhitungan Tingkat Kompetisi antar Murid atau Mahasiswa di Kelas dan Kaitannya Dengan Keadilan Guru atau Dosen Dalam Mengajar. Retrieved from osf.io/a894w 
[4] Sigit Haryadi. (2017). Haryadi Index and Its Applications in Science of Law, Sociology, Economics, Statistics, and Telecommunications. Penerbit Elex Media Komputindo. Jakarta. ISBN978-602-02-9895-5.

[5] Sigit Haryadi. (2017). Indeks Haryadi dan Penerapan di Ilmu Hukum, Sosiologi, Ekonomi, Statistik, dan Telekomunikasi. Penerbit Elex Media Komputindo, Jakarta. ISBN: 978-602-02-9896-2

[6] Sigit Haryadi. (2017). Calculation of the Mobile Communication Competition using Haryadi Index. DOI10.13140/RG.2.2.15634.25280

[7] Haryadi, S. (2018, February 1). Kalkulator Untuk Mengukur Tingkat Kompetisi di suatu Industri, dengan menggunakan rumus Indeks Haryadi. Retrieved from osf.io/fy7zu

[8] Haryadi, S. (2018, February 7). Statistik Terapan: Pengujian Regulasi \& Kebijakan Telekomunikasi. Retrieved from osf.io/3pkfw

[9] Sigit Haryadi. (2018, February). Applied Statistics for Assessment of the Regulation and Policy: case study in Telecommunication Industry.

DOI10.13140/RG.2.2.15774.02884

[10] Haryadi, S. (2018, February 1). Kalkulator untuk membuat Regresi Linier Tanpa Intersep. Retrieved from osf.io/emvs7

[11] Sigit Haryadi. (2017, December). Calculator for non-intercept linear regression. Researchgate. DOI10.13140/RG.2.2.15761.94562.

[12] Sigit Haryadi. (2017, December). Calculator for Measurement the Competition Index \& Level. Researchgate. DOI: 10.13140/RG.2.2.23626.26568

[13] Sigit Haryadi. (2017). The. Fairness over Inequality Index: Unfairness is Disaster - a notebook of Sigit Haryadi. Researchgate. DOI:

10.13140/RG.2.2.34379.49449.

[14] Haryadi, S. (2017, November). Probabilitas Statistik Untuk Insinyur. Researchgate. DOI: 10.13140/RG.2.2.14304.58885

[15] Sigit Haryadi. (2017). Harmony in Gradation and its prospects as the Formula of Everything, First edition of posts: December 31, 2017. Researchgate.

DOI10.13140/RG.2.2.19309.08169

[16] Nie Levin Kusuma Adiatma ; Sigit Haryadi. (2017, October). Comparison of the Haryadi Index with Existing Method in Competition, Equality, Fairness, and Correlation Level Calculation Case Study: Telecommunication Industry. The 11th International Conference on Telecommunication Systems, Services, and Applications, At Lombok, Indonesia.

[17] Sigit Haryadi. (2017). The Non-Intercept Linear Regression Method. Researchgate. DOI10.13140/RG.2.2.18721.71522

[18] Sigit Haryadi. (2017, January). Calculation of the Income Equality Levels between Regions using the Haryadi Index. Researchgate.

DOI10.13140/RG.2.2.36605.77282

[19] Sigit Haryadi. (2016). Haryadi Index for Competition, Equality and Correlation Evaluation. Penerbit Lantip Safari Media, bandung, Indonesia. ISBN 978602-73231-3-2

[20] Sigit Haryadi. (2016). Haryadi Index untuk Evaluasi Kompetisi, Kesetaraan dan Korelasi. Penerbit Lantip Safari Media, bandung, Indonesia. ISBN 978-60273231-3-1 
[21] Haryadi, S. (2018, February 1). Indeks Haryadi dan Prospeknya Untuk Menjadi Suatu "Formula of Everything (versi 31 Desember 2017). Retrieved from osf.io/zex45 